\title{
Geology, Rock Geochemistry and Ore Fluid Characteristics of the Brambang Copper-Gold Porphyry Prospect, Lombok Island, Indonesia.
}

\author{
Aji Syailendra Ubaidillah ${ }^{1,2}$, Arifudin Idrus $^{2^{*}}$, I Wayan Warmada ${ }^{2}$, Syafruddin Maula ${ }^{3}$ \\ ${ }^{1}$ Depatment of Mining Engineering, Universitas Muhammadiyah Mataram, Indonesia. \\ ${ }^{2}$ Department of Geological Engineering, Universitas Gadjah Mada, Yogyakarta, Indonesia. \\ ${ }^{3}$ PT. Buena Persada Mining Services, Jakarta, Indonesia.
}

\author{
* Corresponding author: arifidrus@ugm.ac.id \\ Tel.:+62 81328141648 \\ Received: Dec 28, 2020; Accepted: March 26, 2021 \\ DOI 10.25299/jgeet.2021.6.1.6145
}

\begin{abstract}
Brambang is one of the porphyry copper-gold prospects/deposits situated along eastern Sunda arc. This study is aimed to understand geological framework, alteration geochemistry and ore fluid characteristics of the prospect. Fieldworks and various laboratory analyses were performed including petrography, ore microscopy, rock geochemistry, chlorite chemistry and fluid inclusion microthermometry. The prospect is composed of andesitic tuff and diorite which are intruded by tonalite porphyries. Tonalite porphyries are interpreted as ore mineralisation-bearing intrusion. Various hydrothermal alterations are identified including potassic, phyllic, propylitic, advanced argillic and argillic types. Ore mineralisation is characterized by magnetite and copper sulfides such as bornite and chalcopyrite. Potassic alteration is typified by secondary biotite, and associated with ore mineralisation. Mass balance calculation indicates $\mathrm{SiO}_{2}, \mathrm{Fe}_{2} \mathrm{O}_{3}, \mathrm{~K} 2 \mathrm{O}, \mathrm{Cu}$ and $\mathrm{Au}$ are added during potassic alteration process. Ore forming fluid is dominated by magmatic fluid at high temperature $\left(450-600^{\circ} \mathrm{C}\right)$ and high salinity $(60-70 \mathrm{wt}$. \% $\mathrm{NaCl}$ eq.). Hydrothermal fluid was diluted by meteoric water incursion at low-moderate temperature of $150-400^{\circ} \mathrm{C}$ and salinity of $0.5-7$ wt. \% $\mathrm{NaCl}$ eq.
\end{abstract}

Keywords: Porphyry Cu-Au, Brambang, Lombok, Indonesia

\section{Introduction}

Lombok is one of islands within Nusa Tenggara province cluster. The island is situated in between Sumbawa island in the east, Bali island in the west, Indian ocean in the south and Flores sea in the north (Figure 1). Regionally, Brambang prospect located in south western part of Lombok Island is one of the porphyry copper-gold prospects/deposits identified along west-east trending Sunda-Banda Neogene magmatic arc (Carlile and Mitchell, 1994). In the eastern Sunda arc, several world-class porphyry copper-gold deposits/prospects have been discovered, such as Tumpangpitu in Banyuwangi, East Java, Batu Hijau and Dodo in west Sumbawa, and the latest discovery is Hu'u prospect situated in east Sumbawa (Harrison et al., 2018). Brambang prospect shows a typical porphyry deposit underlain by thick lithocap (Rompo et al., 2012) Only few studies and publications on Brambang prospect and its regional vicinity have been reported by, for instance, Rompo et al., 2012, Setijadji and Maryono, 2012 and Rompo et al., 2012 and Maryono et al., 2018. This study is particularly aimed to update information on the deposit geology, alteration geochemistry and ore forming fluid characteristics, which is at the end for a better understanding of the prospect. 


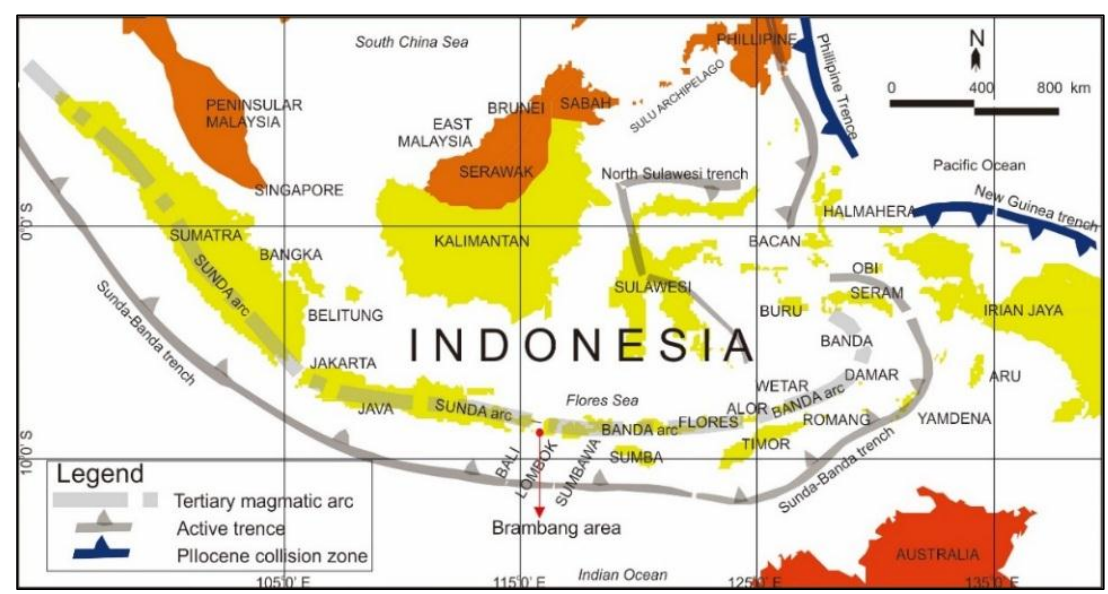

Fig 1. Brambang prospect situated within west-east trending Neogene Sunda-Banda magmatic arc (modified from Hall, 2012).

\subsection{Regional Geology}

Southern part of Lombok island is composed of lithological sequences including Late Oligocene-Middle Miocene andesitic volcanic rocks and intercalated volcanoclastic rocks, which are associated with low-K intermediate intrusive rocks, and shallow marine sedimentary rocks and limestone (Garwin, 2002). Intrusive rocks are commonly cropped out along westeast trending belt of Lombok island. Diorite stocks or dykes are interpreted as the oldest intrusion, which truncated volcanic and sedimentary rocks (Mangga et al., 1994; Figure 2). Tonalite intrusion is spatially and temporally related to porphyry copper mineralisation.
Diatreme breccia complex is mapped out in the periphery of dacite porphyry. The youngest rocks identified in the region is Quarternary volcanic products, which are preserved in the northern part of the island. The occurrence of diatreme breccia may indicate the late phase of magmatic activity, which terminated hydrothermal alteration in the region (Rompo et al., 2012). Mineralisation system in Lombok island consists of porphyry copper-gold, which is superimposed by high-sulfidation epithermal goldsilver. Due to north-south Late Miocene compressional regime, regional structures consisting of north-south extension, folding and trust faults, and NNW-NNE trending strike-slip faults.

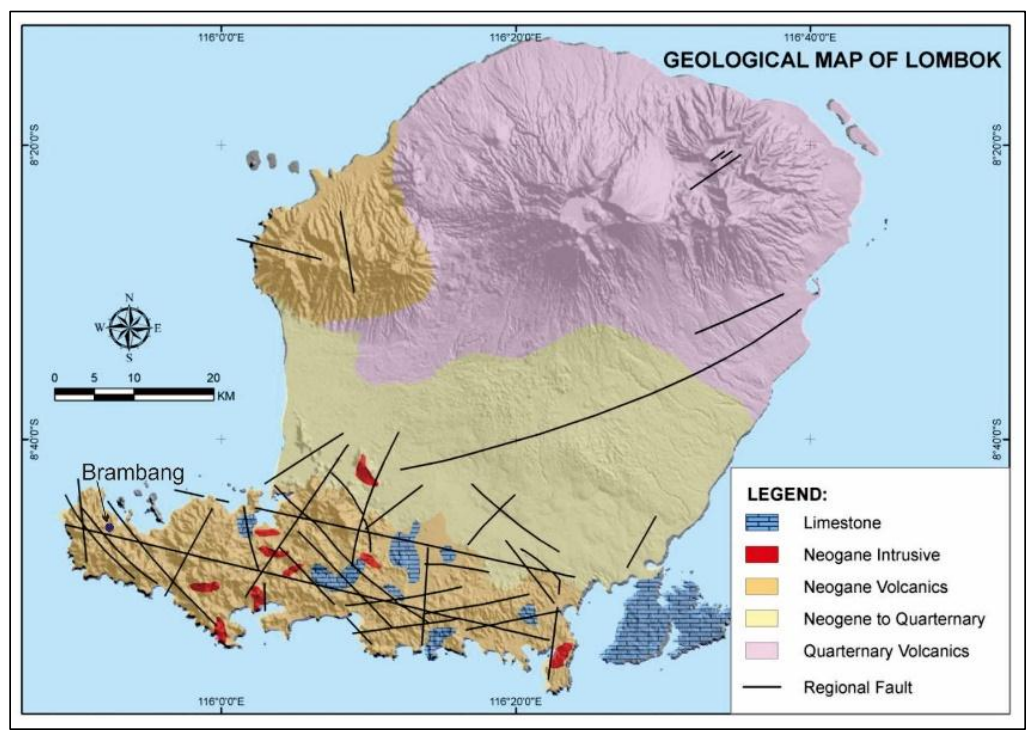

Fig 2. Regional geology of Lombok island (Mangga et al., 1994).

\subsection{Analytical Methods}

In general, research methods are divided into fieldwork and various laboratory analyses. Fieldwork was emphasized on geological and hydrothermal alteration observation. Some representative rock and ore samples were selected for further laboratory analyses. Laboratory analyses consist of mineralogy, bulk-rock geochemistry, ore chemistry and fluid inclusion. Mineralogical study was conducted through petrography and ore microscopy, which were done at
Department of Geological Engineering, Universitas Gadjah Mada. Whole rock geochemical analysis using XRF (X-Ray Fluorescence) and ICP-MS (Inductively Coupled Plasma Mass Spectrometry) methods are to identify the major elements, trace elements, and rare elements in rocks. The whole rock geochemical data of the rocks were then used to calculate mass balance during the hydrothermal alteration process with the isocon method of Grant (1986). Atomic Absorption Spectrometer (AAS) analysis is used to detect metal 
element contents. EPMA (electron probe micro analyser) analysis for chlorite was done in Japanese Atomic Energy Agency (JAEA). Ore forming fluids are characterized by fluid inclusion microthermometric analysis. This analysis is performed by means of Linkam THMS 600 freezing and heating stage at Gifu University, Japan.

\section{Results and Discussion}

\subsection{Lithology and Geochemistry}

Brambang prospect is basically composed of three main rock types including lapilli tuff and diorite and tonalite porphyries. Two previous rock units are intruded by at least three stages of copper-gold bearing tonalite porphyries, so referred to as "old", "intermediate" and "young" tonalite porphyries, respectively. In study area, intermediate and young tonalites have a similar mineralogical arrangement, composed of hornblende, plagioclase, quartz, biotite, magnetite and minor ilmenite. Due to intensive alteration, old tonalite shows more obscured porphyritic texture, containing quartz, k-feldspar, plagioclase biotite and anhydrite. The tonalite porphyries are interpreted to be causative intrusions, which exsolved magmatic hydrothermal fluids, reacting with wallrocks to produce hydrothermal alteration and deposition of copper sulfides and gold. Ore mineralisation is in form of dissemination in the rocks and filling quartz vein/veinlet. Figure 3 is geological map of Brambang prospect showing distribution of tonalite porphyries and wallrocks. Tonalite porphyries as ore mineralisation causative intrusions are also recognized in Batu Hijau (Garwin, 2002; Idrus et al., 2007; (Idrus et al., 2009) and Dodo Elang (Harrison et al., 2018) in Sumbawa Island as well as Tumpangpitu in Banyuwangi, East Java (Hellman, 2010; Harrison et al., 2018).

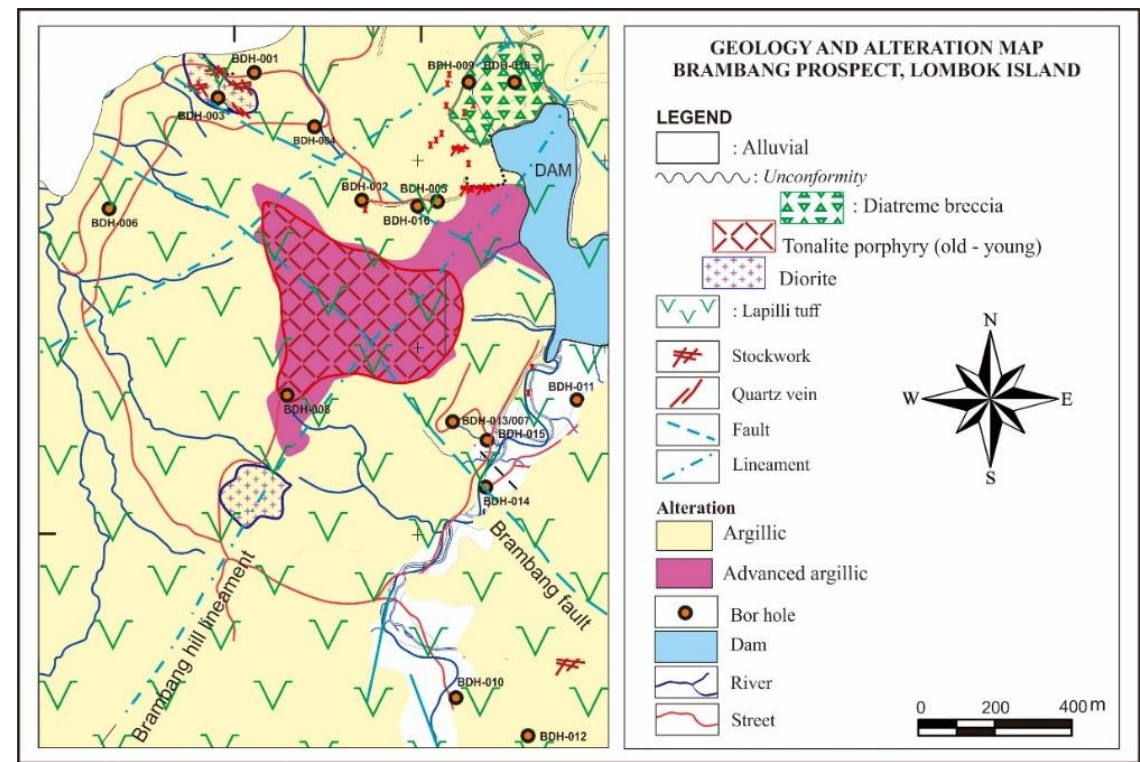

Fig 3. Geological and alteration map of Brambang prospect in SW Lombok Island (modified from PT. Buena Persada Mining Services).

Whole rock geochemical data of pre-mineralisation rocks such lapilli tuff and diorite as well as causative intrusions (tonalite porphyries) are tabulated in Table 1. Fig. 4 shows $\mathrm{Nb} / \mathrm{Y}$ vs $\mathrm{Zr} / \mathrm{TiO}_{2}$ diagram from (Winchester and Floyd (1976) showing lapilli tuff is of andesitic and basaltic compositions. Andesitic-basaltic composition of magma may indicate an island arc setting of subduction (Rollinson, 1993). Bulk geochemical data of four tonalite and two diorite leastaltered samples with $\mathrm{LOI} \leq 5 \mathrm{wt} . \%$ are plotted on diorite and quartz diorite field of (Fig. 5A) and affinity of calcalkaline series (Fig. 5B).

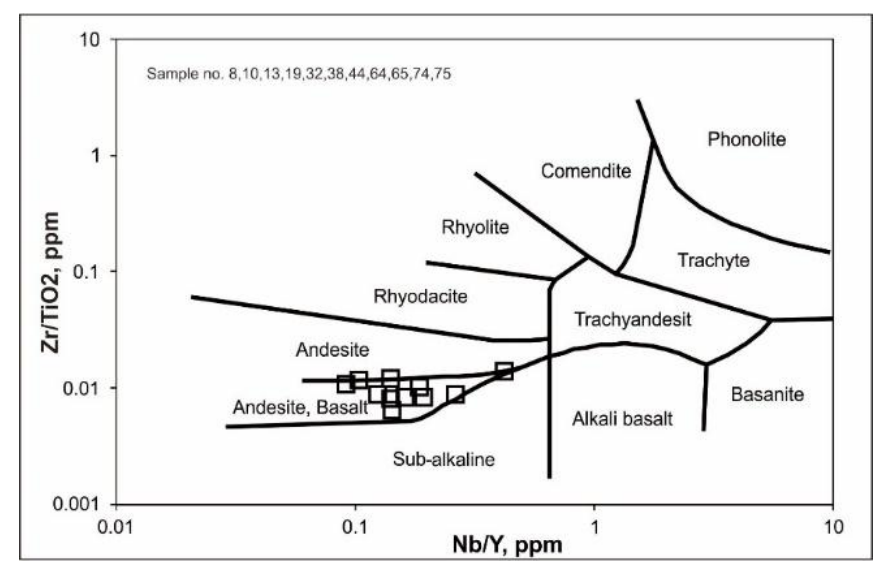

Fig 4. Andesitic-basaltic composition of lapilli tuff from Brambang prospect plotted on Pearce and Wyman (1996). 
Table 1. Whole rock geochemical data of pre-mineralisation rocks and tonalite porphyry from Brambang prospect.

\begin{tabular}{|c|c|c|c|c|c|c|c|c|c|c|c|c|c|c|c|c|c|}
\hline $\begin{array}{l}\text { Rock } \\
\text { Type }\end{array}$ & $\begin{array}{c}\text { Kode } \\
\text { Sampel }\end{array}$ & $\mathrm{SiO}_{2}$ & $\mathrm{TiO}_{2}$ & $\mathrm{Al}_{2} \mathrm{O}_{3}$ & $\mathrm{Fe}_{2} \mathrm{O}_{3}$ & $\mathrm{MnO}$ & $\mathrm{MgO}$ & $\mathrm{CaO}$ & $\mathrm{Na}_{2} \mathrm{O}$ & $\mathrm{K}_{2} \mathrm{O}$ & $\mathrm{P}_{2} \mathrm{O}_{5}$ & LoI & Total & $\mathrm{Ba}$ & $\mathrm{Nb}$ & $\mathrm{Y}$ & $\mathrm{Zr}$ \\
\hline $\begin{array}{c}\text { Lapilli } \\
\text { Tuf }\end{array}$ & 13 & 61,39 & 0,76 & 15,50 & 18,58 & 0,00 & 0,21 & 0,20 & 0,87 & 0,83 & 0,32 & 6,71 & 100,36 & 310 & 1,6 & 13 & 83 \\
\hline $\begin{array}{l}\text { Lapilli } \\
\text { Tuf }\end{array}$ & 8 & 55,42 & 0,83 & 17,29 & 8,60 & 0,26 & 3,51 & 5,61 & 3,59 & 0,14 & 0,14 & 0,17 & 95,56 & 44 & 3,5 & 25 & 100 \\
\hline $\begin{array}{l}\text { Lapilli } \\
\text { Tuf }\end{array}$ & 38 & 63,87 & 0,65 & 14,98 & 10,56 & 0,41 & 3,06 & 2,64 & 1,52 & 0,40 & 0,22 & 4,33 & 100,64 & 76 & 3,4 & 21 & 77 \\
\hline $\begin{array}{c}\text { Lapilli } \\
\text { Tuf }\end{array}$ & 65 & 55,85 & 0,82 & 20,86 & 8,43 & 0,13 & 4,19 & 1,62 & 3,35 & 2,40 & 0,08 & 1,69 & 99,41 & 120 & 3,1 & 22 & 67 \\
\hline $\begin{array}{c}\text { Lapilli } \\
\text { Tuf }\end{array}$ & 19 & 52,83 & 1,22 & 24,71 & 17,34 & 0,00 & 0,11 & 0,03 & 0,21 & 1,78 & 0,10 & 13,92 & 100,25 & 270 & 2,6 & 6,2 & 86 \\
\hline $\begin{array}{l}\text { Lapilli } \\
\text { Tuf }\end{array}$ & 32 & 63,42 & 0,85 & 20,89 & 12,04 & 0,00 & 0,09 & 0,16 & 0,32 & 0,32 & 0,17 & 10,14 & 100,40 & 160 & 2,7 & 14 & 100 \\
\hline $\begin{array}{l}\text { Lapilli } \\
\text { Tuf }\end{array}$ & 75 & 62,57 & 0,90 & 19,59 & 13,32 & 0,00 & 0,07 & 0,19 & 1,04 & 0,76 & 0,22 & 19,43 & 100,09 & 370 & 2,9 & 11 & 99 \\
\hline $\begin{array}{l}\text { Lapilli } \\
\text { Tuf }\end{array}$ & 44 & 60,52 & 0,90 & 21,16 & 9,22 & 0,01 & 0,67 & 0,34 & 0,74 & 4,07 & 0,26 & 8,38 & 100,27 & 140 & 3,3 & 32 & 76 \\
\hline $\begin{array}{l}\text { Lapilli } \\
\text { Tuf }\end{array}$ & 64 & 64,79 & 0,72 & 13,95 & 9,65 & 0,26 & 4,58 & 0,84 & 1,76 & 1,06 & 0,22 & 3,91 & 100,72 & 100 & 4,1 & 22 & 69 \\
\hline $\begin{array}{l}\text { Lapilli } \\
\text { Tuf }\end{array}$ & 10 & 61,98 & 0,56 & 15,96 & 8,04 & 0,12 & 2,43 & 2,34 & 4,33 & 1,81 & 0,19 & 1,91 & 99,67 & 320 & 3,7 & 26 & 85 \\
\hline Diorite & 31 & 60,26 & 0,79 & 18,16 & 8,76 & 0,49 & 3,98 & 2,99 & 2,64 & 0,16 & 0,15 & 5,84 & 100,21 & 53 & 3,2 & 23 & 100 \\
\hline Diorite & 25 & 57,61 & 0,73 & 19,21 & 5,54 & 0,14 & 2,53 & 5,27 & 4,33 & 1,25 & 0,11 & 2,64 & 99,36 & 100 & 3,6 & 19 & 72 \\
\hline $\begin{array}{c}\text { Old } \\
\text { Tonalite }\end{array}$ & 17 & 65,58 & 0,45 & 13,70 & 8,74 & 0,14 & 1,87 & 0,91 & 4,44 & 1,15 & 0,10 & 2,44 & 99,51 & 330 & 2,7 & 12 & 72 \\
\hline $\begin{array}{c}\text { Int. } \\
\text { Tonalite }\end{array}$ & 45 & 55,11 & 0,70 & 17,81 & 13,47 & 0,15 & 3,08 & 1,39 & 3,66 & 1,24 & 0,08 & 3,21 & 99,89 & 90 & 1,2 & 15 & 58 \\
\hline $\begin{array}{c}\text { Int. } \\
\text { Tonalite }\end{array}$ & 33 & 60,64 & 0,91 & 18,58 & 8,42 & 0,20 & 4,39 & 2,37 & 1,04 & 1,12 & 0,16 & 1,00 & 98,82 & 120 & 4,1 & 20 & 95 \\
\hline $\begin{array}{c}\text { Young } \\
\text { Tonalite }\end{array}$ & 72 & 61,16 & 0,55 & 16,55 & 5,68 & 0,08 & 2,29 & 6,41 & 3,57 & 0,75 & 0,14 & 1,75 & 98,93 & 280 & 4,4 & 14 & 88 \\
\hline
\end{tabular}
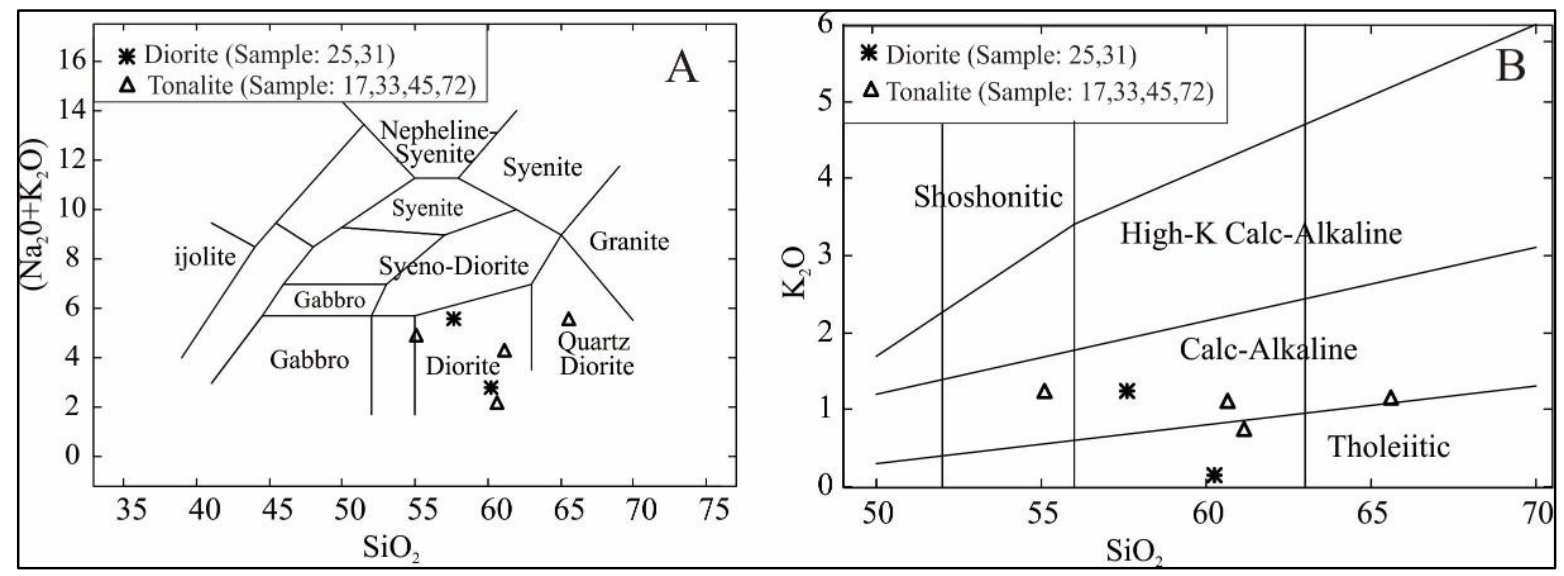

Fig 5. Tonalite porphyry and diorite from Brambang prospect plotted in diorite and quartz diorite fields of Wilson (1989) diagram (A), and mostly plotted as calc-alkaline affinity on Peccerillo and Taylor, (1976) diagram (B).

\subsection{Hydrothermal Alteration and Ore Mineralisation}

Five alterations types are identified in Brambang prospect both surface and subsurface including potassic, phyllic, propylitic, advanced argillic and argillic. However, on the surface, only two alterations are mappeable i.e. advanced argillic and argillic types (Figure 3). Potassic, phyliic and propylitic alteration zones were identified in drillcore samples. Potassic alteration is the earliest phase of hydrothermal alteration associated with the first tonalite intrusion. This phase is characterized by the process of forming secondary biotite from mafic minerals (hornblende and primary biotite).

Mafic minerals including hornblende and secondary biotite were chloritized particularly during phyllic and propylitic alteration. Chlorite geothermometry was applied on the basis of formula of Cathelineau (1988). The formation temperature of chlorite in propylitic- 
and phyllic-altered rocks from the Brambang prospect varies from 309 to $332^{\circ} \mathrm{C}$. The chlorite formed at similar temperatures in both alteration zones which may suggest overprinting system by later stage of hydrothermal activity. Advanced and argillic alteration was superimposed on the earlier alteration zones such as potassic, phyllic and propylitic types.

Hydrothermal alteration processes result in mass changes altered rocks which can be in the form of gains or losses to oxides and minor elements in rocks. Mass balance calculations generally use the Gresens (1967)'s method modified by Grant (1986). To calculate the mass balance, representative samples of an altered rock, as well as an unaltered rock (or least-altered) were used. The immobile elements ( $\mathrm{Al}, \mathrm{Ti}, \mathrm{Ga}, \mathrm{Hf}$ and HREE as Tb, Dy, Ho, Er, Tm, Yb and Lu) are commonly used for isocon parameters (Ulrich and Heinrich, 2001; Hezarkhani, 2002; Idrus et al., 2009). The Isocon gradient is calculated from immobile element concentration of the original (least-altered) samples as precursor and altered rock samples. Mass balance of some potassic-altered rocks taken from drillcores have been studied in comparison to propylitic-altered rocks as precursor (Figure 6). When normalised to the propylitic-altered rocks, the potassic-altered tonalite shows a decrease in the mass and volume (6.54 \pm 1.78 and $8.64 \pm 1.74 \%$, respectively). In potassic alteration the main elements such as $\mathrm{SiO}_{2}, \mathrm{Fe}_{2} \mathrm{O}_{3}, \mathrm{~K}_{2} \mathrm{O}, \mathrm{Cu}$, Au and $\mathrm{S}$ tend to be added, while $\mathrm{MgO}$ and $\mathrm{CaO}$ are depleted during alteration process (Figure 6). Those elemental gains and loses implies a strong association between potassic altered rocks (addition in secondary biotite) with ore mineralisation, which is marked by the presence of magnetite and copper-bearing sulfides. Copper and gold shows a positive correlation, and their grades increase by increasing of $\mathrm{SiO}_{2}$ concentration (Figure 7). This may suggest that copper and gold grades increase with increasing the intensity of quartz vein/veinlet stockwork. Bornite, chalcopyrite, digenite and chalcocite are the copper-bearing sulfides identified in association with alteration type.

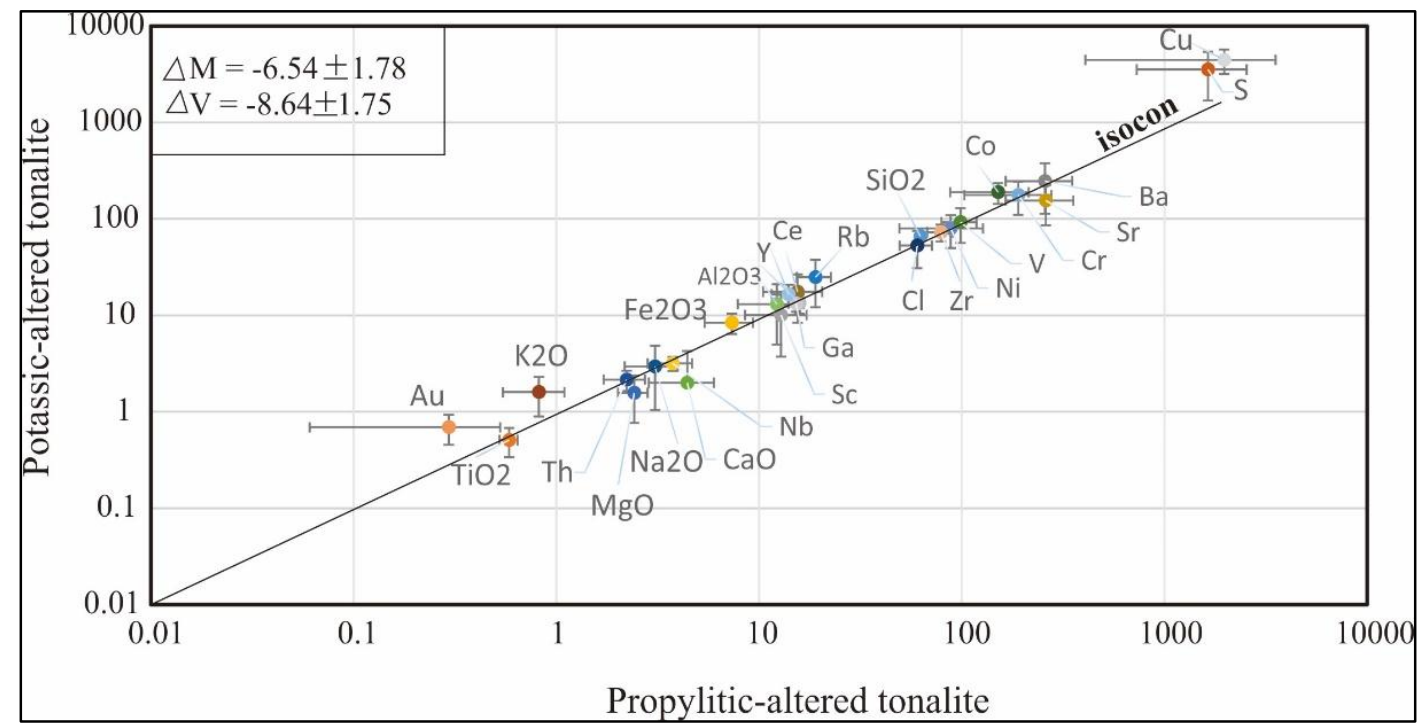

Fig 6. Elemental mass balance between propylitic-altered tonalite as precursor and potassic altered old tonalite porphyry.
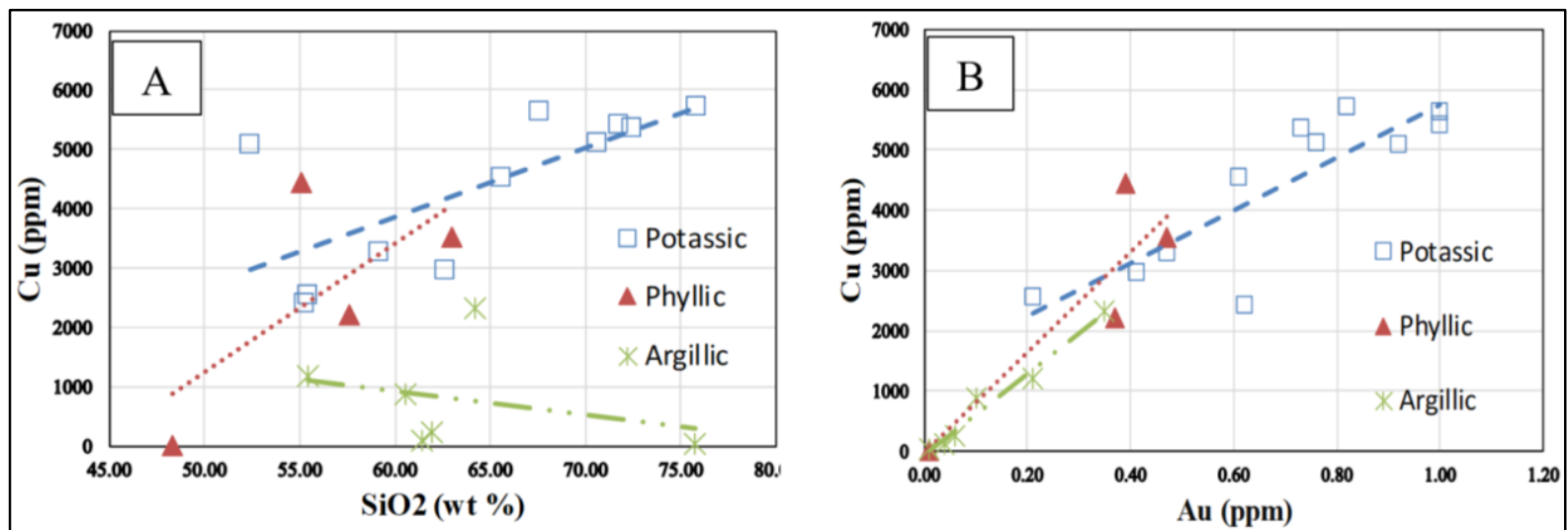

Fig 7. $\mathrm{SiO}_{2}$ vs $\mathrm{Cu}(\mathrm{A})$ and $\mathrm{Au}$ vs $\mathrm{Cu}(\mathrm{B})$ diagram showing a positive correlation.

\subsection{Ore-forming Fluid Characteristics}

The quartz veins/veinlet system in the research area can be divided into five types including $M, A, B, C$ and $D$ (Gustafson and Hunt, 1975). Fluid inclusion studies were done for $A, A B, B$ and $D$ quartz vein/veinlet types. Nash (1976) showed three typical fluid inclusions found in porphyry deposit. Type I $(\mathrm{L}+\mathrm{V})$ called moderate salinity type, characterized by liquid phase volume more dominant rather than vapor phase and 
trace of the daughter minerals. Type II called (V-rich) type, characterized by dominantly vapor phase $(>60 \%)$ to liquid phase, and frequently found daughter mineral such as hematite. Type III $(\mathrm{L}+\mathrm{V}+\mathrm{S})$ called halite-bearing type, which mostly contain cubic halite, sylvite, hematite and anhydrite daughter minerals (Fig. 8). The type II and III fluid inclusions in type A, B, and AB quartz veins indicate high homogenization temperature of $450-600^{\circ} \mathrm{C}$ ) and high salinity (60-70 wt. \% $\mathrm{NaCl}$ eq.) (Figure 9), which corresponds to pressure of $\sim 300$ bar and depth of $\sim 3 \mathrm{~km}$ from paleosurface. Fluid inclusion microthermometric data from $\mathrm{D}$ veins indicates lowmoderate temperature and salinity fluid of $150-400^{\circ} \mathrm{C}$ and 0.5-7 wt. \% $\mathrm{NaCl}$ eq., respectively (Fig. 9).

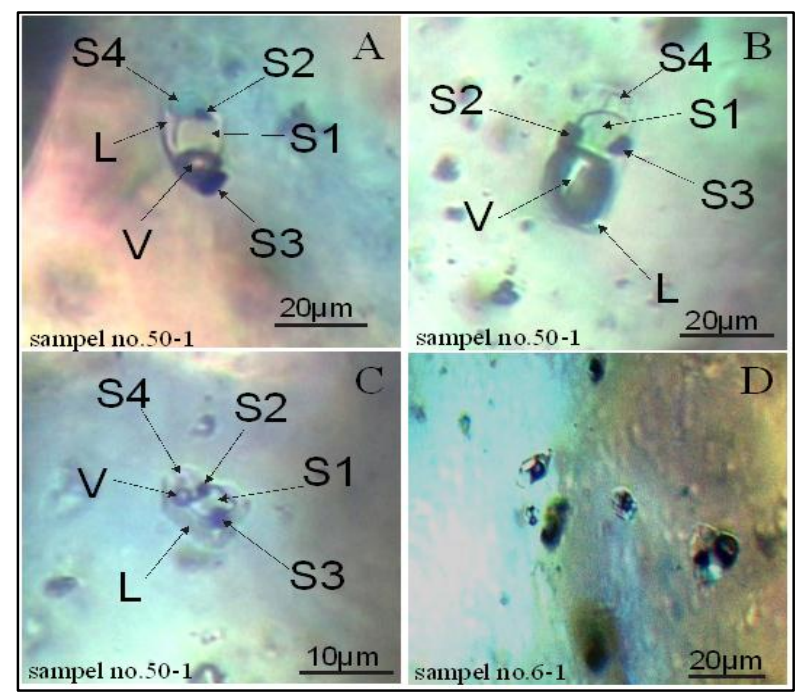

Fig 8. Petrography of Type III fluid inclusions (L-V-S1-S2-S3) hosted by $A, A B$ and $B$ quartz vein.

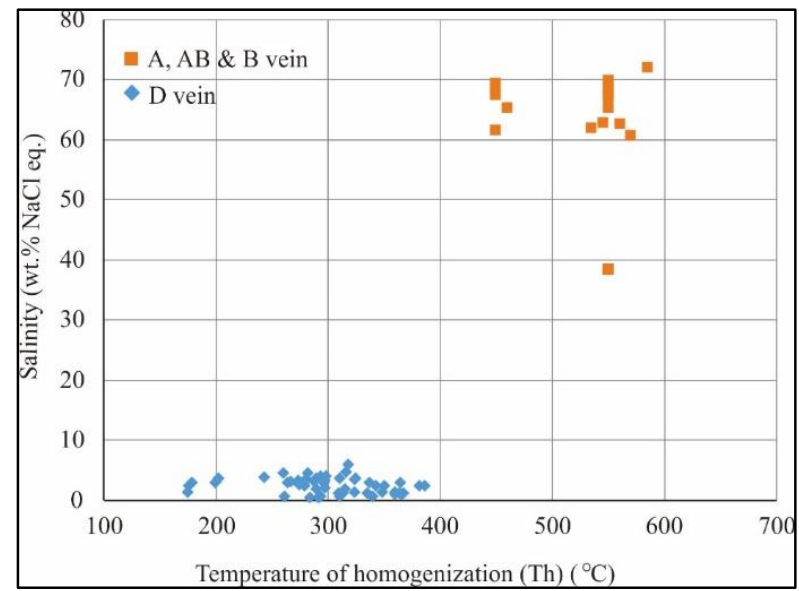

Fig 9. Temperature of homogenization (Th) vs salinity diagram of fluid inclusions hosted by $A, A B, B$ and $D$ quartz veins in Brambang prospect.

\section{Conclusion}

Brambang prospect shares some key features which are similar to the classical porphyry copper-gold prospect/deposits, particularly those occurred along eastern Sunda magmatic arc. The prospect is composed of three main rock types including lapilli tuff and diorite, which are intruded by at least three stages of copper-gold bearing tonalite porphyries, so referred to as "old", "intermediate" and "young" tonalite porphyries, respectively. The prospect is centered by potassic, phyllic, propylitic, advanced argillic and argillic alterations. Chlorite thermometry suggests temperature of formation for chlorite associated with phyllic or propylitic alteration varies between 309 to $332^{\circ} \mathrm{C}$. Ore mineralisation marked by the presence of secondary magnetite and several high-temperature copper sulfides such as bornite and chalcopyrite is spatially and temporally rrelated to the potassic alteration. The addition of $\mathrm{SiO}_{2}, \mathrm{~K}_{2} \mathrm{O}$ and $\mathrm{Fe}_{2} \mathrm{O}_{3}$ is along with the enrichment of $\mathrm{Cu}, \mathrm{S}$ and $\mathrm{Au}$ during potassic alteration process. The Brambang ore mineralisation was originated by magmatic hydrothermal fluid at high temperature of $450-600^{\circ} \mathrm{C}$ and salinity of $60-70 \mathrm{wt} . \%$ $\mathrm{NaCl}$ eq., which corresponds to pressure of $\sim 300$ bar and depth of $\sim 3 \mathrm{~km}$ from paleosurface. Fluid inclusion microthermometric data of $\mathrm{D}$ vein show low-moderate temperature and salinity fluid of $150-400^{\circ} \mathrm{C}$ and $0.5-7$ wt. \% $\mathrm{NaCl}$ eq., respectively. This temperature might be representative of the formation of argillic and advanced argillic alteration.

\section{Acknowledgements}

The authors wish to express a deep gratitude to the management of PT. Buena Persada Mining Services, which has given permission to do investigation and drillcore sampling in Brambang prospect. The authors also thank to Prof. Tomoyuki Ohtani from Gifu University, Japan for providing various laboratory facilities during the first author research visit. This study was made possible through the financial support from Ministry of National Education, The Republic of Indonesia.

\section{References}

Carlile, J.C., Mitchell, A.H.G., 1994. Magmatic arcs and associated gold and copper mineralization in Indonesia. J. Geochem. 50, 91-142.

Cathelineau, M., 1988. Cation Site Occupancy in Chlorite and Illites as a Function of Temperature. Mineral. Soc. 471-485.

Garwin, S., 2002. The Geologic Setting of Intrussiorelated Hydrothermal Systems Near The Batu HIjau Porphyry Copper-Gold Deposit, Sumbawa, Indonesia. Soc. Econ. Geol. 333-366.

Grant, J.A., 1986. The isocon diagram-a simple solution to Gresens' equation for metasomatic alteration. Econ. Geol. 81, 1976-1982. https://doi.org/10.2113/gsecongeo.81.8.1976

Gresens, R.L., 1967. Composition-volume relationships of metasomatism. Chem. Geol. 2.

Gustafson, L., Hunt, J., 1975. The porphyry copper deposit at El Salvador, Chile. Econ. Geol. 857-912.

Hall, R., 2012. Tectonophysics Late Jurassic - Cenozoic reconstructions of the Indonesian region and the Indian Ocean. Tectonophysics 570-571, 1-41. https://doi.org/10.1016/j.tecto.2012.04.021

Harrison, R.L., Maryono, A., Cooke, D.R., Rompo, I., Hoschke, T.G., 2018. Tectonics and geology of porphyry $\mathrm{Cu}-\mathrm{Au}$ deposits along the eastern Sunda magmatic arc, Indonesia. Econ. Geol. 113, 7-38.

Hellman, P.L., 2010. Tujuh Bukit Project Report on Mineral Resources, Located in East Java, 
Indonesia. Tech. Rep. Interprid Mines Limited.

Hezarkhani, A., 2002. Mass changes during hydrothermal alteration/mineralisation in a porphyry copper deposit, eastern Sungun, northwestern Iran . J. Asian Erath Sci. 20, 567588.

Idrus, A., Jochen, K., Michael, F.M., 2007. Chemical Composition of Rock-Forming Minerals in Copper - Gold-Bearing Tonalite Porphyries at the Batu Hijau Deposit, Sumbawa Island, Indonesia : Implications for Crystallization Conditions and Fluorine - Chlorine Fugacity 57, 102-113. https://doi.org/10.1111/j.17513928.2007.00010.x

Idrus, A., Kolb, J., Meyer, F.M., 2009. Mineralogy, lithogeochemistry and elemental mass balance of the hydrothermal alteration associated with the gold-rich Batu Hijau porphyry copper deposit, Sumbawa Island, Indonesia. Resour. Geol. 59, 215-230.

Mangga, S.A., Atmawinata, S., Hermanto, B., Setyogroho, B., Amin, T., 1994. Peta Geologi Lembar Sumbawa, Nusa Tenggara Barat. Bandung, Indonesia.

Nash, J.T., 1976. Data from PorpHyry Copper Deposits and Applications to Exploration: Reston, VA, United States, U. S. Geological Survey D1-D16.

Pearce, J., Wyman, D., 1996. A users guide to basalt discrimination diagrams, Trace Element
Geochemistry of Volcanic Rocks: Applications for Massive Sulphide Exploration. Geol. Assoc. Canada, Short Course Notes 12, (pg. 79-113).

Peccerillo, A., Taylor, S.R., 1976. Geochemistry of eocene calc-alkaline volcanic rocks from the Kastamonu area, northern Turkey. Contrib. to Mineral. Petrol. $58,63-81$.

Rollinson, H.R., 1993. Using Geochemical Data: Evaluation, Presentation, Interpretation.

Rompo, I., Rowe, A., Maryono, A., 2012. Porphyry Cu-Au and EpithermalAu-Ag Mineralization Systems in South West Lombok.

Setijadji, L.D., Maryono, A., 2012. Geology and Arc Magmatism of the Eastern Sunda Arc , Indonesia.

Ulrich, T., Heinrich, C.A., 2001. Geology and alteration geochemistry of the porphyry $\mathrm{Cu}-\mathrm{Au}$ deposit at Bajo de la Alumbrera, Argentina. Econ. Geol. 96, 1719-1742.

Wilson, M., 1989. Igneous Petrogenesis, Unwin Hyman, London.

Winchester, J.A., Floyd, P.A., 1976. Geochemical Discrimination of Different Magma Series and their Differentiation Products Using Immobile Elements 20, 325-343.

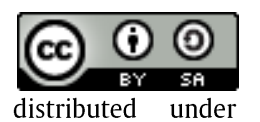

(C) 2021 Journal of Geoscience, Engineering, Environment and Technology. All rights reserved. This is an open access article distributed under the terms of the CC BY-SA License (http://creativecommons.org/licenses/by-sa/4.0/). 